\title{
組立作業用技能システムの一構成法
}

\author{
村川洋介* 内 山勝*
}

\section{An Approach to the Design of a Skill System for Assembly Tasks}

\author{
Yousuke MURAKAWA Masaru UCHIYAMA
}

To enhance the ability of robot manipulators to be applied to assembly tasks in unstructured environments, intelligent control to extend the autonomy of the manipulator is urgently required. The concept of the intelligent control, however, has not been established although many approaches have been presented. This paper presents an approach to the implementation of artificial skill-artificially realized human physical skill to be controlled intelligently-that combines the framework of symbolic manipulation by Lisp and the framework of hybrid control of positions and forces that has been presented for the control of constrained motion. First, on the analogy of human brain that implements natural skill, the control system is designed hierarchically, of which the upper level consists of recognition and planning systems based on specially designed rules and the lower level consists of a hybrid controller written by C. An important part is the interface between the upper and lower levels, which is designed in order for the framework of the hybrid control to be matched with the upper level. The above design framework is applied to a special task:a peg-in-hole task, to yield a skill system for the task. Simulation results show that the system controls the task successfully.

Key Words : Robot Manipulator, Intelligent Control, Artificial Skill, Automatic Assembly, Hybrid Control.

\section{1. 序論}

ロボットにとって複雑な環境や，未知の環境で作業を 行わせる場合には，口ボット自身が環境や操作対象の変 化を認識し，適切な動作を行っていく必要がある．この ような知能ロボットの制御において，過去に習得された 知識の果たす役割は大きい, 人間が過去に習得した知識 にもとづいて状況を判断し，個々の動作を適切に制御す る能力を, 本論文では技能と呼ぶ. そして, ロボットに よって実現された同様の能力を人工技能と呼ぶ゙. これ を実現するためには，七ンサ情報やサーボレベルの制御 情報と, 認知判断や動作計画などの高度な情報処理との 連携を, どのように行うかといら, システムの設計法が 問題となる.そこで我々は, 人間の技能行動の発現機構

原稿受付 1990 年 3 月 27 日

* 東北大学工学部
についての知見をモデルとし，人工技能システムの一構 成法を提案する.

人間の技能行動の発現機構は, 以下のようであるとい われている2). 運動全体の計画は前頭前野で行われ, 個 々の運動の発現は, 運動前野にあらかじめ用意されてい る運動パターンを起動することによって行われる（運動 レパートリー). 起動された運動パターンは小脳・運動 野を経て筋肉への動作指令となる. 感覚領野の一部には, この動作指令を受け取って, 特定の動作を行なっている 時にのみ反応して認識を行ら部分がある.このような動 作と結び付いた認識を, アクティブタッチと呼ぶ3)（視 覚の場合にはダイナミックビジョンと呼ばれる4)).

本論文では, 以上の知見をもとに, コンピュータ上に ルールベーストな人工技能システムを構成する. そして 組立作業シミュレータを対象に, ハイブリッド制御を用 いた作業実験を行い, その機能を確かめる. 
組立作業における接触状態については，その識別可能 性を論じた研究占や, 組立の運動学・静力学を定式化し, 部品の幾何モデルから識別手続きを自動生成する手法を 提案した研究6)などがある.これらの手法では静力学的 な解析に基づいて識別を行っているが，それのみでは一 意に状態を決定するのが困難である場合がありうる，そ こで動作指令を含めて識別手続きを構成する手法 (アク ティブベリフィケーション) が提案されている7).これ は前述のアクティブタッチと同様の考方方であり, 我々 の手法とも共通する.

またルールベースシステムによってロボットを制御し ようとする研究としては，オペレータの効果が不明な状 況から動作を通じて必要なマクロオペレータを獲得する 万法が提案されている81.

\section{2. 人工技能の構成法}

\section{1 全 体構成}

新たな技能行動を習得する際には，既に習得している 技能を組み合わせて数多くの練習をするなど, 高度な知 能の働きが必要であるが, 一旦習得した技能行動は, 半 ば無意識の状態で実行できることからわかるように，さ ほど高度な知能の働きは必要とされない91.であるなら ば、アプリケーションとしての人工技能を考えた場合に は, 習得能力を省いたレディメードの技能パッケージと いら方法も十分ありらる，そこで，本論文では，既に修 得した技能を発現させる機構の実現を目指す. その習得 過程については, 基本的なアイデアを示すにとどめる.

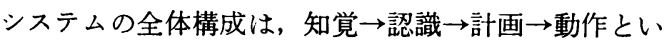
らループを描いている. 認識・計画等を行う部分は記号 処理的な機能が主となるが, 実際の動作を行っている部

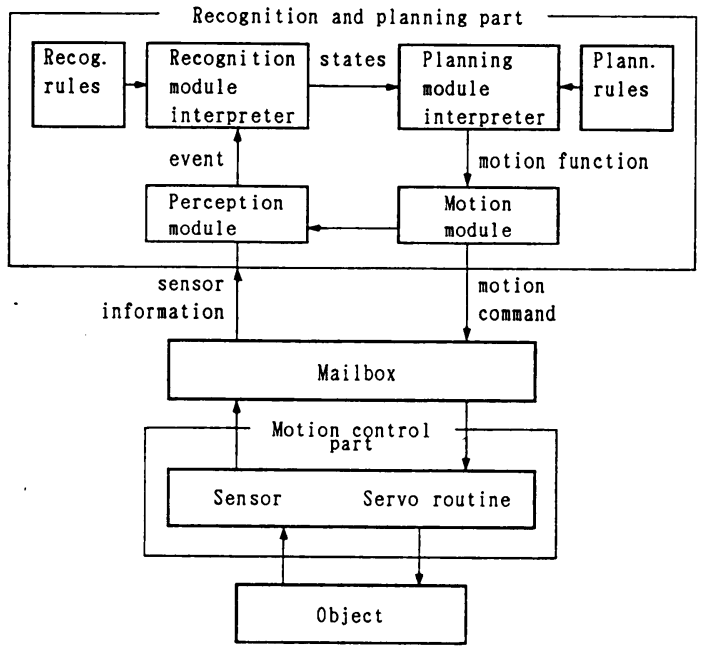

Fig. 1 Artifitial skill system
分では数值データの取り扱いが主となる．また認知サイ クルと動作のサーボサイクルでは，必要とされる時間に 10 倍以上の開きがある.そこで, 認識・計画モジュール を含む部分（認知計画部）と，知覚・運動モジュール末 端でセンサやサーボに関わる制御部は, 独立した別プロ セスとする，そして両プロセス間では，非同期の通信機 能を用いて連絡をとることにする（Fig. 1).

認知計画部内の知覚・認識・計画の各モジュール間の 情報の伝達には，イベントといら概念を用いる.イベン トは，その認知サイクルに発生した新たな信号や認識, 動作指令などを示すもので，全てのモジュールから発生 し, 認識・計画の各モジュールでの判断に用いられる.

認識モジュールと計画モジュールの中核は, イベント に基づいてルールの選択発火を行らプロダクションシス テムで，それぞれに用いられるルール群が用意されてい る.これらのルール群は、インタープリタが効率的に処 理できるように，前処理が施されている。

以下に各モジュールごとの機能を示す。

\section{2 知覚モジュール}

知覚モジュールは，センサ信号に対してフィルタをか けて，必要な情報を取り出す機能を持つ。センサから得 られた数值データは，まず作業記憶要素の值としてその まま記憶される．次にその值を前回の值と比較して，し きい值以上の変動があった場合には，UP，DOWNなど の定性的な記述の作業記憶を生成し，それをイベントと して登録する.この知覚イベントは，特定の属性ごとに グループ化してあり, そのグループ内では一つのイベン トのみが発生するようになっている (Table 1). 動作に 応じて，しきい值のレベルを制御することにより，想定 通りに作業が進行している時には不要な情報は考慮せず，

Table 1 Examples of event group

\begin{tabular}{|c|c|c|}
\hline Group name & Event name & Meaning \\
\hline $\begin{array}{l}\text { wms\$ } \\
\text { horizonal }\end{array}$ & $\begin{array}{l}\text { wm\$horizonal_left } \\
\text { wm\$horizonal_stop } \\
\text { wm\$horizonal_right }\end{array}$ & $\begin{array}{l}\text { Moving to left } \\
\text { Not moving } \\
\text { Moving to right }\end{array}$ \\
\hline wms \$momen t & $\begin{array}{c}\text { wm\$momentright_up } \\
\text { wm\$momentright_even } \\
\text { wm\$momentright_down } \\
\text { wm\$momentsmall_even } \\
\text { etc. }\end{array}$ & $\begin{array}{l}M^{-1} \text { is increasing } \\
M R \text { is constant } \\
M R \text { is decreasing } \\
M S \text { is constant }\end{array}$ \\
\hline wms\$turn & $\begin{array}{l}\text { wm\$turn_left } \\
\text { wm\$turn_stop } \\
\text { wm\$turn_right }\end{array}$ & $\begin{array}{l}\text { Turning to left } \\
\text { Not turning } \\
\text { Turning to right }\end{array}$ \\
\hline $\begin{array}{r}\text { wms \$push\& } \\
\text { pull }\end{array}$ & $\begin{array}{l}\text { wm\$pushed_up } \\
\text { wm\$pushed_even } \\
\text { wm\$pushed_down }\end{array}$ & $\begin{array}{l}\mathrm{PF}^{\cdot 2} \text { is increasing } \\
\mathrm{PF} \text { is constant } \\
\mathrm{PF} \text { is decreasing }\end{array}$ \\
\hline$* 2$ & $\begin{array}{l}\text { MR means "moment to } t \\
\text { MS means "very small } \\
\text { PF means "pushed forc }\end{array}$ & $\begin{array}{l}\text { n right" and } \\
\text { ment". }\end{array}$ \\
\hline
\end{tabular}


逆に想定外の異常な入力があった場合には，すぐに対応 寸ることができるようになる。

\section{3 認識モジュール}

認識モジュールでは, 知覚モジュールで発生したイべ ントと,それまでの作業の経緯・動作指令などをもとに して対象物の状態を推定し，その記述を生成する。この 認識の生成に用いられるルール群は, 作業内容や対象物 によって異なってくる，そこで，各単位作業ごとに必要 なルールサブセットを構成し, 計画モジュールのサブセ ットにあわせて選択する。

現在得られている情報から, 状態が一意に定まらない 場合や, あてはまる状態が見つからない場台は, 状態を 「不明 (unknown)」とし, 計画モジュールに探索動作を 要請する (アクティブタッチ). そして次の認知サイク ルで, 動作モジュールの行ったアクティブタッチ動作に 対するセンサ入力から, 状態を推定する.

\section{4 計画モジュール}

計画モジュールでは, 認識モジュールの出力をもとに, 作業目的を達成するよらな動作の系列を計画する． 1. で述べた運動レパートリーの機能を実現するために, 次 のような機能を用いる. まず, 条件に応じて特定の動作 パーンを発現する動作ルールを，多数用意する．次に， 特定の作業目的を遂行するために，必要なルールを集め たサブセットをいくつか作り，登録しておく，そして专 際の作業を行う時には，各単位作業ごとに必要なサブセ ットを選択し，状況にあわせてルールを発火させていく ことによりその単位作業を遂行する（Fig. 2).

\section{5 動作モジュール}

動作モジュールは, 計画モジュールで発火したルール に記述されている動作指令にもとついて，運動制御を行 うモジュールである。認知計画部内の動作モジュールは 制御部との通信機能を持った関数群からなり, 制御部内

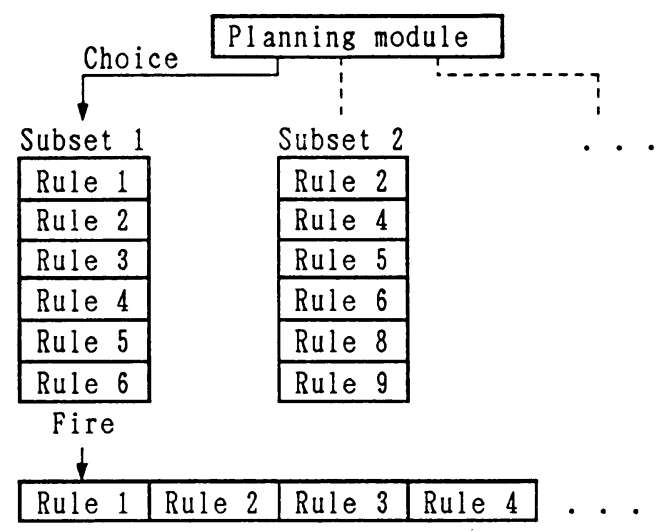

Fig. 2 Motion repertory and rule sutsets
のモジニーハは，指令にもとついてモータの制御を行ら サーボループを構成している，ルール内に記运されてい る動作指令は対象物レベルのものなので, これをコマン ドレベルに分解・変換寸る必要があり, 作業座漂の管理 等も行ら必要がある.

\section{6 技能の習得}

技能の習得は本論文の目的ではないが，以上の枠組み の中で，それがどのように実現できるかを考えておくこ とは重要である，本システムでは，新たな課題を遂行す る技能の習得は, 基本的にはルールサブセットの再構成 によって行ら。+ブセットの再構成は, 次の 5 段階にわ たって行われる.

（1）与えられた新課題を分析して，既に習得してい るルールサブセットの内で, その課題を遂行できる, あ るいはできそうなものを探す。

（2）単一の+ブセットでは遂行できそらにない場合 は, 課題を分割して各々の部分を遂行できるものを探し, 組み合わせる。

（3）（1），（2）で選択された新サブセットによっ て, 課題を実行する.

（4）失敗した場合にはその原因を探し，新たなルー ルを加えるか，特定のルールを除いて繰り返す。あるい は，（1），(2）に戻ってサブセットごと組み直す.

（5）一応成功するようになっても何度も実行を絽り 返し, 常に連続して発火するルールを一体化したり, 逆 にまったく発火しないルールを除いて, サブセットを洗 練させて行く.

このような機梓を実現するためには，充分な数のルー ル群と模範的なサブセット群を準備し，作業の類似性を 判断する，失敗につながったルールを捨て，㓢なルール を取り込む，といった機能を実現させる必要がある。た だし，作業の類似性の判断は，完全にプログラムによの て行うことは現時点では困難であり，人間側から教示寸 る必要があろう。奏現するための手がかりとして，作業 の効果 (移動の方向, 距離, 变形, 結合, 離脱) や, 必 要な力（上下方向か水平方向か）、エネルギーといった 指標を用いて作業を評価することで，ある程度類似性の 推定もできるのではないかと考えられる，また，ルール の取捨選択も，失敗の原因推定に難しい面もあり，人間 の教示によりカバーする必要があろう。

\section{3. インプリメンテーション}

以上の考皇にもとづく人工技能システムをコンピュー タ上に構築し，作業実験を行った．使用したコンピュー 夕はVAX STATION II/GPX であり, 認知計画部の 記述には Lispを、制御部の記述にはC 言話を用いた。 


\section{1 作 業 対 象}

作業対象には，野崎らが開発した円柱形のぺグをホ ールに插入する組立作業シミュレータを用いる（Fig. 3) ${ }^{10111)}$. このシミュレータは, ペグ重心に対して加える 力とモーメントを入力すると, 慣性やホール壁面との接 触・摩摖などのダイナミックスを考慮してペグの運動を 計算し，画面上に表示するものである. ホール座標から 見たピンの位置や角度，ペグにかかる反力，ペグとホー ルの接触状態 (ステート) などのデータは, シミュレー ション中に自由に取り出すことができる.

目標と寸る単位作業は，空中で保持しているぺグをホ ールの中に插入するといらものである. ホールの位置や 方向はおおよそしか与えられておらず，ペグを用いて手 探りで探索する必要がある. 今回の実験では，ペグはホ ールの左上から接近することにする. ペグとホールの諸 元及び初期位直を Table 2 に示す.

\section{2 知営モジュール}

認知計画部内の知覚モジュールでは, 制御部から送ら れてきたペグの位置と加えられた力の情報をもとにして， イベントを発生させる. 今回用いた知覚イベントのグル ープ名とその意味を Table 3 に示す.

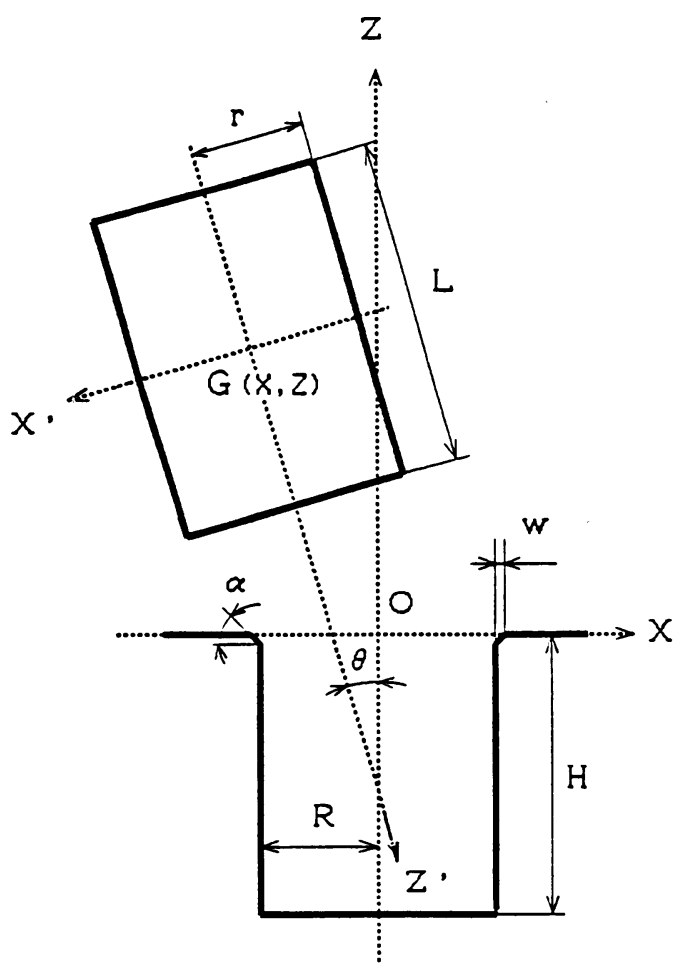

Fig. 3 Peg-in-hole simulator ; $(X, Z)$ is the hole frame and $\left(X^{\prime}, Z^{\prime}\right)$ is the peg frame

\section{3 認識モジュール}

作業対象の状態の内部表現は, 基本的には野崎らの定 義したシミュレータのステートを用いる(Fig.4).これ らのステートは, シミュレーションを行らための力学的 な解析から得られたもので, 運動方程式の違いに対応し ている11. ただしこれらのステート区分は，必ずしも作 業状態の認識とは一致していない，例えばステート $\mathrm{E}$, $\mathrm{F}, \mathrm{G}, \mathrm{J}, \mathrm{K}, \mathrm{M}, \mathrm{N}, \mathrm{O}$ などは，「挿入中の状態」とし て認識させることもでき，またそのように一括して取り 扱った方が，ルール構成が自然になると考えられる。 そ こでこれらのステートは区別せずにMで代表させる. また野崎らの定義していないつまり状態をOJ として別 に定義し，判別できない場合をUNKNOWN とする.

これらの状態認識を発生させるルールは, 2.3 で示し たよらに, 前回の動作指令, 前回のステート, 知覚イへ ントを条件部とし，現在のステートを実行部とする形式 で構成する.ルールの記述は経験にもとついて行い, 各 ステートについて，条件部の各要素の組み合わせごとに 複数のルールを作成した. Table 4 にその 1 例を示す. 表中で, Old state は前回の状態, Motion command は 動作指令, Fired events は成立している知覚イベントで, その意味は Table 1 に示す.これらの条件が満たされた とき Current state と判断する. なお No.7 のルールは 動作指令にかかわりなく成立し，知覚イベントにより判 断する.

Table 2 Parameters for the peg-in-hole task

\begin{tabular}{|l|l|}
\hline Hole hight H & $0.1(\mathrm{~m})$ \\
\hline \begin{tabular}{l} 
llole radius R \\
\hline Peg length L
\end{tabular} & $0.05(\mathrm{~m})$ \\
\hline $\begin{array}{c}\text { Peg clearance } \\
\mathrm{R}-\mathrm{r}\end{array}$ & $0.11(\mathrm{~m})$ \\
\hline \begin{tabular}{|l|}
$\mathrm{X}$ \\
Peg mass
\end{tabular} & $0.2\left(10^{-3} \mathrm{~m}\right)$ \\
\hline \begin{tabular}{l} 
Friction coe. \\
\hline
\end{tabular} & 0.1 \\
\hline Rebound coe. & 0.0 \\
\hline
\end{tabular}

a) Physical parameters

b) Initial position of the peg with respect to the hole frame

Table 3 Event groups for the sensor module

\begin{tabular}{|l|l|}
\hline Group name & \multicolumn{1}{|c|}{ Meaning } \\
\hline wms\$vertical & $\begin{array}{l}\text { Vertical movement with re- } \\
\text { spect to the control frame. }\end{array}$ \\
\hline wms\$orizonal & $\begin{array}{l}\text { Horizontal movement with re- } \\
\text { spect to the control frame. }\end{array}$ \\
\hline wms\$turn_0 & $\begin{array}{l}\text { Indices to show if the peg } \\
\text { is standing vertically. }\end{array}$ \\
\hline wms\$urn & Rotation. \\
\hline wms\$push\&pull & $\begin{array}{l}\text { Change of vertical force on } \\
\text { the peg. }\end{array}$ \\
\hline wms\$moment & Change of moment. \\
\hline
\end{tabular}




\section{4 動作モジュール}

ペグの運動制御にはハイブリッド制御を用いる. 認知 計画部からは，モード選択ベクトルと制御目標値を制御 部に送信し，制御部では，送られてきた目標值を選択べ クトルに従って解釈し，指定された制御則で制御する. 制御則の指定は, Raibert らの定義 ${ }^{22}$ 徒亏。制御用座 標系は, 認知計画部から変更指示があった時に, その時 点でのペグ座標系に固定する.

制御部の動作モジュールでは，サンプリングタイム 2 $\mathrm{ms}$ で制御を行う，上位モジュールとの通信は 10 サン プリングタイム毎に mailbox を検査し, 通信プロトコル にもとついて指令を解积する.

1 回の認知実行サイクルには, 知覚モジュールからの 情報要求指令と動作モジュールからの制御指令の 2 回の 指令が必要なため, $40 \mathrm{~ms}$ の時間がかかる.

\section{5 計画モジュール}

計画モジュールのルール内で用いられる動作命令の一 覧を, Table 5 と示す. 制御目標值は制御座標系で表し た位置または力であり，選択べクトルによって確定する。 また $\mathrm{px}-\mathrm{c}, \mathrm{pz}-\mathrm{c}$ はペグの現在位置の $\mathrm{X}, \mathrm{Z}$ 座標の値で ある.これらの動作命令を用いて，次のような方策で動 作計画を行う.

（1）接触していない状態（ステートA）あるいは状 態が不明の場合には，ゆっくりペグを下ろす（slowdown).

（2）一点で表面に触れ，表面の方向が不明な場合 （ステート B， L，S）は，ペグを押し付けて表面の方向 を確定する (touchsurface).

（3）ペグ底面が表面に接触した状態（ステートC） になったら，その方向を記憶する（touchsurface）.
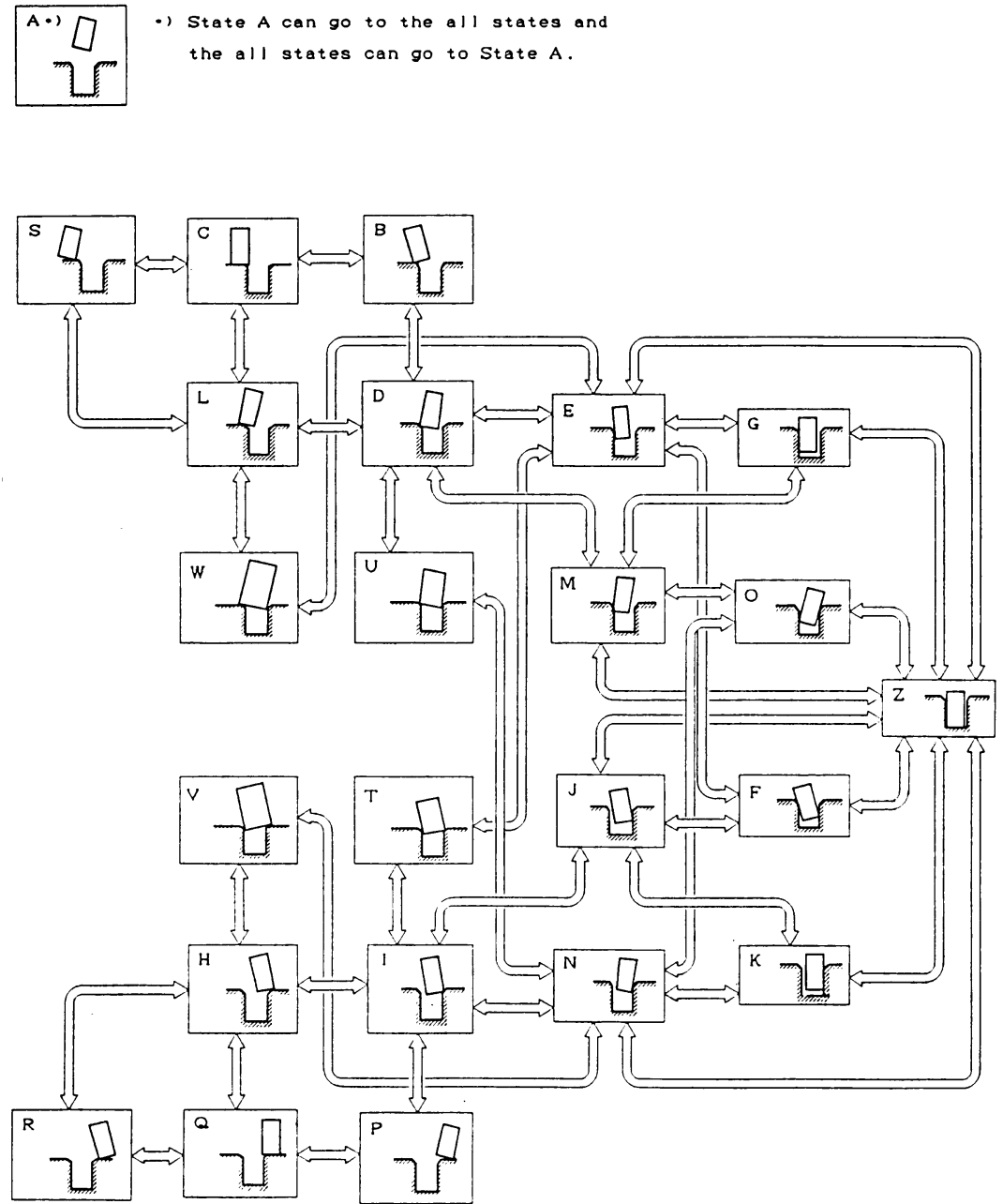

Fig. 4 States of peg-in-hole 
Table 4 Examples of recognition rule

\begin{tabular}{|c|c|c|c|}
\hline \multirow{2}{*}{ No. } & \multirow{2}{*}{$\begin{array}{l}\text { 0ld } \\
\text { state }\end{array}$} & Motion command & \multirow{2}{*}{$\begin{array}{c}\text { Current } \\
\text { state }\end{array}$} \\
\hline & & Fired events & \\
\hline \multirow[b]{2}{*}{1} & \multirow[b]{2}{*}{ UNKNOWN } & slowdown & \multirow[b]{2}{*}{ c } \\
\hline & & $\begin{array}{l}\text { wm\$turn_stop } \\
\text { wm\$pushed_even } \\
\text { wm\$momentsmall_even }\end{array}$ & \\
\hline \multirow[b]{2}{*}{2} & \multirow[b]{2}{*}{ UNKNOWN } & slowdown & \multirow[b]{2}{*}{ c } \\
\hline & & $\begin{array}{l}\text { wm\$turn_stop } \\
\text { wm\$pushed_up } \\
\text { wm\$momentsmall_even }\end{array}$ & \\
\hline \multirow{2}{*}{3} & \multirow{2}{*}{ UNKNOWN } & slowdown & \multirow{2}{*}{$S$} \\
\hline & & $\begin{array}{l}\text { wm\$pushed_even } \\
\text { wm\$momentright_even }\end{array}$ & \\
\hline \multirow{2}{*}{4} & \multirow{2}{*}{ UNKNOWN } & slowdown & \multirow{2}{*}{$S$} \\
\hline & & $\begin{array}{l}\text { wm\$pushed_up } \\
\text { wm\$momentright_even }\end{array}$ & \\
\hline \multirow{2}{*}{5} & \multirow{2}{*}{$S$} & touchsurface & \multirow{2}{*}{ c } \\
\hline & & $\begin{array}{l}\text { wm\$momentsmall_even } \\
\text { wm\$turn_stop }\end{array}$ & \\
\hline \multirow{2}{*}{6} & \multirow{2}{*}{ B } & touchsurface & \multirow{2}{*}{ c } \\
\hline & & $\begin{array}{l}\text { wm\$momentsmall_even } \\
\text { wm\$turn_stop }\end{array}$ & \\
\hline \multirow{2}{*}{7} & \multirow{2}{*}{ c } & (any command) & \multirow{2}{*}{ L } \\
\hline & & $\begin{array}{l}\text { wm\$horizonal_right } \\
\text { wm\$turn_right }\end{array}$ & \\
\hline
\end{tabular}

（4）表面が確定したら，ペグを斜めに傾けて（ステ ートS）ホールの探索を始める (slide, goright).

（5）ホールの縁にペグが当たったら（ステート N, W), ホールに対してペグを直立させる（turn， stop).

(6) ペグが直立したら（ステート E, F, G, J, K, $\mathrm{M}, \mathrm{N}, \mathrm{O}$ ), 挿入する (push).

（7）途中で詰まった場合には（ステート OJ）引き 抜き，再び挿入する（pull, push).

これらのらち（1），（2）は, 䜑識に必要な情報を得 るための動作であり, アクティブタッチの一つの実現で ある・

\section{4. シミュレーション結果}

以上のシステムにより,シミュレーションを行った.

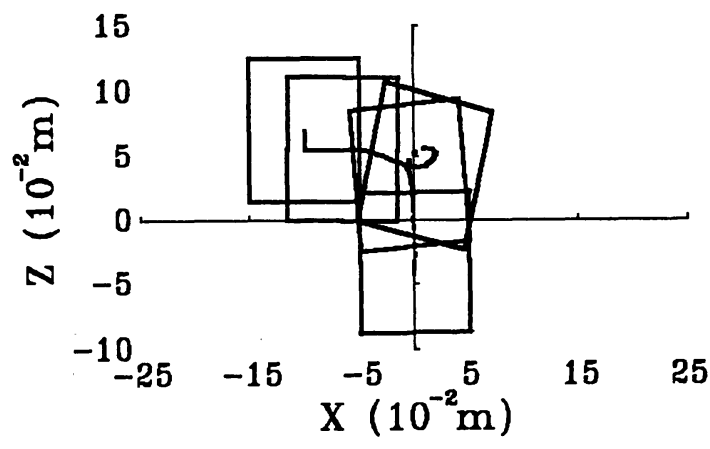

Fig. 5 Trajectory of the peg
Table 5 Motion commands

\begin{tabular}{|c|c|c|c|}
\hline \multirow{2}{*}{\multicolumn{2}{|c|}{$\frac{\text { Motion name }}{\text { slowdown }}$}} & $S \cdot 1$ & Target $\cdot 2$ \\
\hline & & $\left(\begin{array}{lll}1 & 0 & 1\end{array}\right)$ & 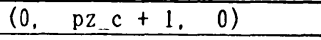 \\
\hline \multirow{2}{*}{$\begin{array}{l}\text { touch- } \\
\text { surface } \dot{e}^{3}\end{array}$} & a) & $\left(\begin{array}{lll}0 & 0 & 0\end{array}\right)$ & Change the control frame \\
\hline & b) & $\left(\begin{array}{lll}1 & 1 & 1\end{array}\right)$ & $(0,0.01,0)$ \\
\hline \multicolumn{2}{|l|}{ slide } & $\left(\begin{array}{lll}0 & 1 & 0\end{array}\right)$ & $\left(p x_{-} c-1,0.01,-4\right)$ \\
\hline \multicolumn{2}{|l|}{ goright } & $\left(\begin{array}{lll}0 & 0 & 0\end{array}\right)$ & $\left(p x_{-} c-1,0,-4\right)$ \\
\hline \multicolumn{2}{|l|}{ push } & $\left(\begin{array}{lll}1 & 0 & 1\end{array}\right)$ & $(0, \quad p z c+1$ \\
\hline \multicolumn{2}{|l|}{ turn } & $\left(\begin{array}{lll}1 & 1 & 0\end{array}\right)$ & $(0,-1.5,4)$ \\
\hline \multicolumn{2}{|l|}{ stop } & $\left(\begin{array}{lll}1 & 1 & 0\end{array}\right)$ & $(0,-1.5,0)$ \\
\hline \multicolumn{2}{|l|}{ pull } & $\left(\begin{array}{lll}1 & 1 & 1\end{array}\right)$ & $\left(\begin{array}{lll}0, & -2, & 0\end{array}\right)$ \\
\hline
\end{tabular}

*1 Compliance selection vector. $\left(S_{x} S_{z} S_{\theta}\right)$.

*2 Units are ( $\mathrm{N}$ or $10^{-2} \mathrm{~m}, \mathrm{~N}$ or $10^{-2} \mathrm{~m}, \mathrm{~N} \cdot \mathrm{m}$ or $\mathrm{deg}$ ). respectively, according to the selection vector $S$.

*3 If rotation of the peg stops then do a) else do b).

その結果を Fig. 5-8 に示す.

Fig. 5 はペグの重心の移動と, 角度の変化を示したも のである. Fig. 6 は, シミュレータからのステータス出 力と, 認識結果を比較している.この図では, ステータ ス A， B， C , . を を順に $0,1,2, \ldots$ とする表現を用い ている. 24 は OJ, 25 は UNKNOWN を表す.また, 各々の時点で用いられた制御モードを Fig. 7 に示す.

Fig. 8 はペグに加えられた力とモーメントを示す. Fig. 6-8 の横軸は, 認知実行サイクル $(40 \mathrm{~ms} / \mathrm{cycle})$ を表す.

Fig. 6 より，認識モジュールはシミュレータの出力と ほぼ等しい状態認識をしていることがわかる．Fig. 8 で は、ペグがフリーの状態では， Fz は重力を打ち消すた めに $-0.2(\mathrm{~N})$ 近くの值を示す. 插入過程でも, Fzは ほぼ0から -0.2（N) の間の値となっており, ペグが スムーズに挿入されていることがわかる，このとき， F $\mathbf{x}$ と Moment については, 制御モードが目標值 0 の力制 御であるため，0のままである。

\section{5. 結 論 と展 望}

技能を構成する各要素に要求される機能を考察し, 人 工技能を構成する場台のひとつの方針を示した，また，

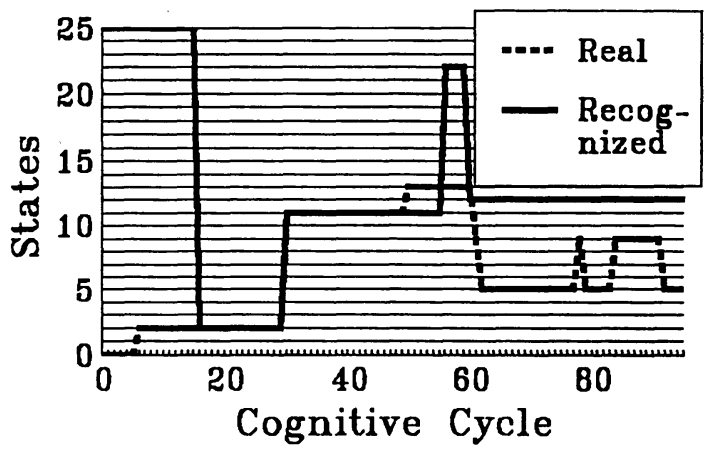

Fig. 6 Real states and recognized states Februaay, 1991 

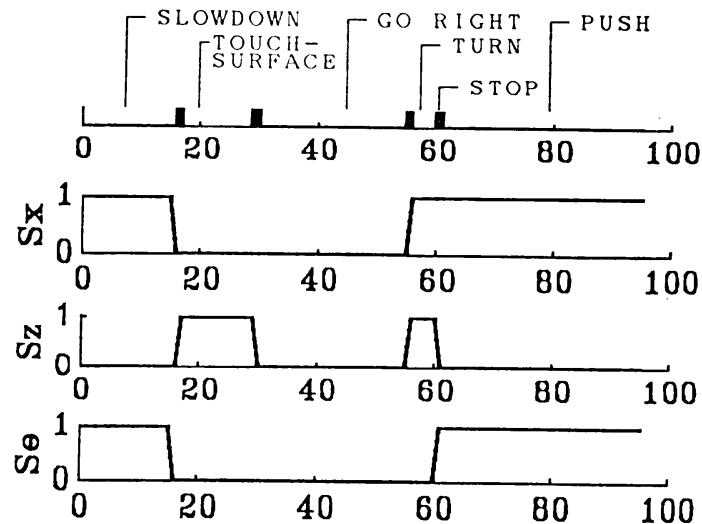

\section{Cognitive Cycle}

Fig. 7 Compliance selection vector for the hybrid control

その方針にもとついて、サーボレベルにハイブリッド制 御を用いたぺグ挿入組立作業を行ら技能システムを構成 し,シミュレーションにより，その機能を確認した。

今後の研究課題として以下の課題があげられる.

（1）作業対象の幾何学的な表現を内部モデルとして 用い,ルールの記述に抽象性, 汎用性を持たせる.

（2）充分な数のルール群と, 基本的なサブセット群 を準備し，適用可能な作業の範囲を広げる。

（3）技能学習の機能を実現する.

\section{謝辞}

本研究は, 電子技術総合研究所の小笠原司・松井俊浩 両氏によって開発された ETALisp を用いて行われた. またプログラム開発にあたっては, 同研究所の北垣高成 氏の協力を得た．以上の諸氏に感謝の意を表する。

\section{参考文 献}

1）高瀬國克, “ロボットのスキルと知能”, 日本機械学会口 ボティクス・メカトロニクス講演会'89 講演概要集, pp. 32-33, 1989

2）、澤口俊之, “知性の脳構造之進化”, pp. 5-44, 海鳴社, 1989

3）岩村吉晃，“触るーアクティブタッチの神経機構”，脳と 認識, pp. 145-165, 平凡社, 1982

4) 浅田 稔, “ダイナミックビジョン”, 計測と制御, Vol 29, No.3, pp. $226-231,1990$

5) T. Lozano-Perez, M. T. Mason and R. H. Taylor, "Automatic Synthesis of Fine-Motion Strategies for Robots", The Int. J. of Robotics Reserch, Vol.3, No.1, po. 3-24, 1984

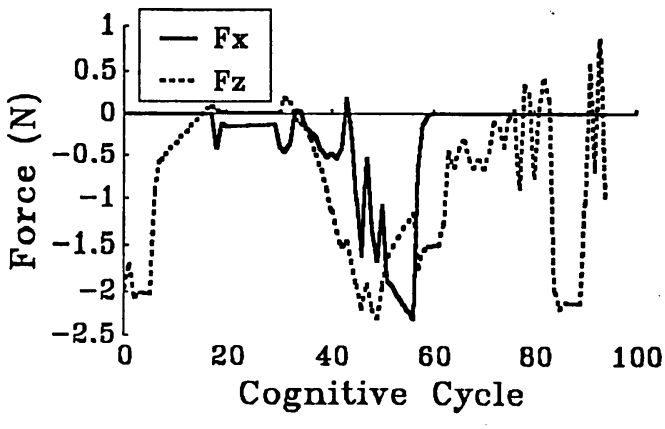

(w) $\mathrm{Fx}, \mathrm{Fz}$

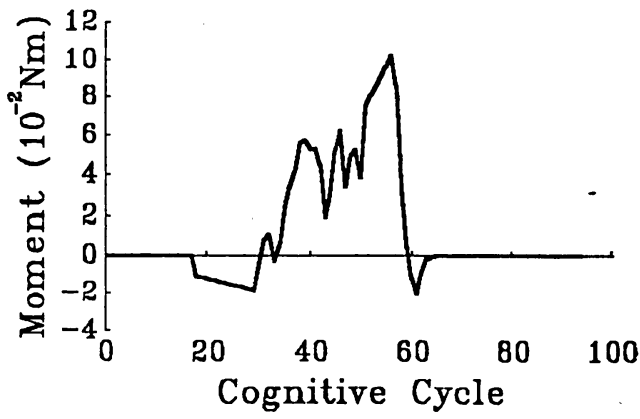

(b) Moment

Fig. 8 Forces and moment applied to the peg

6）平井慎一，浅田春比古，得丸英勝，“組立作業における 接触状態の位置・力信号の解釈による識別とモデルをむ とにした識別手続きの自動生成”，計測自動制御学会論 文集, Vol 26, No.2，pp. 225-232，1990

7) R.S. Desai and R.A. Volz, "Identification and verificatin of termination conditions in fine motion in presence of sensor errors and geometric uncertainties", Int. Conf. on Robotics and Automation 1989, pp. $800-807$

8）三浦 純，下山 勲，三浦宏文，“知能ロボットにおけ る問題解決と学習の統合”, 日本ロボット学会誌, Vol.8, No. 3, pp. 281-291, 1990

9）ピーターソン, “学習心理学入門”, 新曜社, pp. 89-116, 1977

10) M. Uchiyama and T. Toyofuku, "Simulation of constrained motion in robotized assembly", Proc. of the 20 th Int. Symposium on Industrial Robots, pp. 601-608, 1989

11）野崎秀洋，内山 勝，豊福贵司，“組立作業における拘 束運動のシミュレーション", 第 7 回日本ロボット学会 学術講演会予講集, pp. 519-520, 1989

12) M. H. Raibert and J. J. Craig, "Hybrid Position/force Control of Manipulators", J. of Cynamic Systems, Measurement, and Control, 102, pp.126-133, 1981 